ARTICLE

\title{
The $\gamma$-tubulin-specific inhibitor gatastatin reveals temporal requirements of microtubule nucleation during the cell cycle
}

Takumi Chinen², Peng Liu², Shuya Shioda ${ }^{3}$, Judith Pagel², Berati Cerikan², Tien-chen Lin², Oliver Gruss², Yoshiki Hayashi ${ }^{4}$, Haruka Takeno ${ }^{4}$, Tomohiro Shima ${ }^{5} \dagger$, Yasushi Okada ${ }^{5}$, Ichiro Hayakawa ${ }^{6}$, Yoshio Hayashi ${ }^{4}$, Hideo Kigoshi ${ }^{3}$, Takeo Usui ${ }^{1} \&$ Elmar Schiebel $^{2}$

Inhibitors of microtubule (MT) assembly or dynamics that target $\alpha / \beta$-tubulin are widely exploited in cancer therapy and biological research. However, specific inhibitors of the MT nucleator $\gamma$-tubulin that would allow testing temporal functions of $\gamma$-tubulin during the cell cycle are yet to be identified. By evolving $\beta$-tubulin-binding drugs we now find that the glaziovianin A derivative gatastatin is a $\gamma$-tubulin-specific inhibitor. Gatastatin decreased interphase MT dynamics of human cells without affecting MT number. Gatastatin inhibited assembly of the mitotic spindle in prometaphase. Addition of gatastatin to preformed metaphase spindles altered MT dynamics, reduced the number of growing MTs and shortened spindle length. Furthermore, gatastatin prolonged anaphase duration by affecting anaphase spindle structure, indicating the continuous requirement of MT nucleation during mitosis. Thus, gatastatin facilitates the dissection of the role of $\gamma$-tubulin during the cell cycle and reveals the sustained role of $\gamma$-tubulin.

\footnotetext{
${ }^{1}$ Graduate School of Life and Environmental Sciences, University of Tsukuba, 1-1-1 Tennodai, Tsukuba 305-8572, Japan. ${ }^{2}$ Zentrum für Molekulare Biologie der Universität Heidelberg, ZMBH-DKFZ Alliance, Im Neuenheimer Feld 282, Heidelberg 69120, Germany. ${ }^{3}$ Graduate School of Pure and Applied Sciences, University of Tsukuba, 1-1-1 Tennodai, Tsukuba 305-8571, Japan. ${ }^{4}$ Department of Medicinal Chemistry, Tokyo University of Pharmacy and Life Sciences, Hachioji, Tokyo 192-0392, Japan. ${ }^{5}$ Laboratory for Cell Polarity Regulation, RIKEN Quantitative Biology Center, Suita 565-0874, Japan. ${ }^{6}$ Division of Applied Chemistry, Graduate School of Natural Science and Technology, Okayama University, 3-1-1 Tsushima-naka, Kita-ku, Okayama 700-8530, Japan. †Present address: Department of Biological Sciences, Graduate School of Science, University of Tokyo, 2-11-16 Yayoi, Bunkyo-ku, Tokyo 113-0032, Japan. Correspondence should be addressed to T.U. (email: usui.takeo.kb@u.tsukuba.ac.jp) or to E.S. (email: e.schiebel@zmbh.uni-heidelberg.de). Requests for materials should be addressed to T.U. (email: usui.takeo.kb@u.tsukuba.ac.jp).
} 
M icrotubules (MTs) are dynamic polymers of $\alpha / \beta$-tubulin heterodimers that are involved in a wide variety of biological functions such as mitosis, organelle positioning and cell motility. MTs are inherently polar structures with $\alpha$-tubulin terminating the MT minus end and $\beta$-tubulin the MT plus end. While $\alpha / \beta$-tubulin heterodimers can spontaneously polymerize to generate MTs in vitro, MT nucleation in vivo is initiated from a ring-like template of $\gamma$-tubulin (another member of the tubulin superfamily) that can promote MT nucleation at concentrations below those required for spontaneous assembly ${ }^{1-3} \cdot \gamma$-Tubulin recruits accessory proteins, so-called $\gamma$-tubulin complex proteins (GCPs). $\gamma$-Tubulin, GCP2 (ref. 4) and GCP3 (ref. 5) form a tetrameric 2:1:1 complex named the small $\gamma$-tubulin complex ( $\gamma$-TuSC). In many eukaryotes, $\gamma$-TuSC assembles with additional GCPs (GCP4-6) into the stable $\gamma$-tubulin ring complex $(\gamma \text {-TuRC })^{6}$. Despite the importance of $\gamma$-tubulin function for MT formation, $\gamma$-tubulin-specific MT nucleation inhibitors are yet to be reported. This deficiency in our drug repertoire limits the temporal analysis of $\gamma$-tubulin functions in eukaryotic cells to lengthy short interfering RNA (siRNA) depletion experiments that arrest cells in prometaphase because of spindle assembly checkpoint (SAC) activation after sustained deficiency in $\gamma$-tubulin functions for many hours before observation. We therefore lack a clear understanding of the requirements of $\gamma$-tubulin at discrete cell cycle phases that arises from acute inhibition of $\gamma$-tubulin functions through pharmacological intervention.

Here we used recombinant human $\gamma$-tubulin to screen for $\gamma$-tubulin inhibitors and identified the AG1 (refs 7,8) derivative gatastatin $^{9}$ as $\gamma$-tubulin-specific inhibitor. Gatastatin blocked $\gamma$-tubulin-dependent MT nucleation, without affecting $\alpha / \beta$-tubulin polymerization. Gatastatin identified novel $\gamma$-tubulin functions for metaphase spindle maintenance and anaphase spindle elongation. These data demonstrate the continuous importance of $\gamma$-tubulin throughout the cell cycle for MT homeostasis.

\section{Results}

Screening of $\boldsymbol{\gamma}$-tubulin binders from $\alpha / \beta$-tubulin inhibitors. $\gamma$-Tubulin shares $34 \%$ similarity with $\beta$-tubulin (UniProtKB/ Swiss-Prot: P23258.2 and Q13509.2). This prompted us to ask whether it would be possible to develop $\gamma$-tubulin-specific inhibitors from known drugs that bind to the colchicine-binding site in $\beta$-tubulin, for example, nocodazole, plinabulin ${ }^{10}$ and glaziovianin $A^{7,8}$ (AG1). We screened a collection of $\beta$-tubulin colchicine-site binders for binding to human $\gamma$-tubulin (Table 1 and Supplementary Fig. 1). The correct folding of the purified, recombinant $\gamma$-tubulin was confirmed by two criteria. First, $\gamma$-tubulin bound $\alpha-\left[{ }^{32} \mathrm{P}\right]-$ GTP with high affinity ${ }^{11}$ (Supplementary Fig. 2a). Second, purified human $\gamma$-tubulin and GCP4 assembled into a stable complex ${ }^{12}$ (Supplementary Fig. 2b).

Changes in tryptophan fluorescence of $\gamma$-tubulin were used as a test for drug binding ${ }^{13}$. Nocodazole and plinabulin both bound $\gamma$-tubulin, however, with a markedly lower affinity than for $\alpha / \beta$-tubulin $\left(K_{\mathrm{d}}[\alpha / \beta\right.$-tubulin $] / K_{\mathrm{d}}[\gamma$-tubulin $]<0.05$; Table 1$)$. In contrast, AG1 bound $\gamma$-tubulin $\left(K_{\mathrm{d}}=85.3 \mu \mathrm{M}\right.$, Table 1$)$ and $\alpha / \beta$-tubulin with similar $K_{\mathrm{d}}$ values $\left(K_{\mathrm{d}}[\alpha / \beta\right.$-tubulin $] / K_{\mathrm{d}}$ $[\gamma$-tubulin $]=0.61)$. Thus, AG1 binds to both $\gamma$-tubulin and $\alpha / \beta$-tubulin.

To identify molecules that showed selectivity for $\gamma$-tubulin over $\alpha / \beta$-tubulin, we synthesized derivatives of both plinabulin and AG1 and tested their binding affinity for $\gamma$-tubulin and $\alpha / \beta$-tubulin. KPU-406, one of the plinabulin derivatives (Supplementary Fig. 1), bound to $\gamma$-tubulin $\left(K_{\mathrm{d}}=46.1 \mu \mathrm{M}\right.$, Table 1) and $\alpha / \beta$-tubulin with similar $K_{\mathrm{d}}$ values

\begin{tabular}{|c|c|c|c|}
\hline & \multicolumn{2}{|c|}{$K_{d}(\mu M)^{\star}$} & \multirow{2}{*}{ 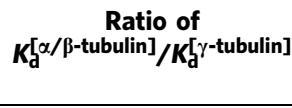 } \\
\hline & $\alpha / \beta$-Tubulin & $\gamma$-Tubulin & \\
\hline Colchicine & $17.5 \pm 2.7$ & $196.4 \pm 47.9$ & 0.09 \\
\hline Nocodazole & $1.8 \pm 0.6$ & $54.9 \pm 19.0$ & 0.03 \\
\hline Plinabulin & $0.5 \pm 0.1$ & $83.3 \pm 18.5$ & 0.01 \\
\hline KPU-406 & $26.3 \pm 2.0$ & $46.1 \pm 27.6$ & 0.57 \\
\hline$A G 1$ & $51.9 \pm 36.4$ & $85.3 \pm 22.8$ & 0.61 \\
\hline Gatastatin & $42.5 \pm 36.7$ & $3.6 \pm 1.3$ & 11.81 \\
\hline
\end{tabular}

*The $K_{d}$ value of each drug was calculated from tryptophan fluorescence decrease $(\Delta \mathrm{FL})$ from three independent experiments using the GraphPad Prizm software. Values are the mean \pm s.d.

$\left(K_{\mathrm{d}}[\alpha / \beta\right.$-tubulin $] / K_{\mathrm{d}}[\gamma$-tubulin $\left.]=0.57\right)$. Interestingly, the AG1 derivative gatastatin (Fig. 1a) had a markedly 12 -fold higher affinity for $\gamma$-tubulin $\left(K_{\mathrm{d}}=3.6 \mu \mathrm{M}\right.$, Table 1$)$ than for $\alpha / \beta$-tubulin $\left(K_{\mathrm{d}}[\alpha / \beta\right.$-tubulin $] / K_{\mathrm{d}}[\gamma$-tubulin $\left.]=11.81\right)$. These data suggest that gatastatin binds relatively specific to $\gamma$-tubulin.

Gatastatin is a $\gamma$-tubulin-specific inhibitor. We next investigated the impact of gatastatin on MTs assembled from purified tubulin in the absence of $\gamma$-tubulin. In sharp contrast to AG1, which inhibits dynamic behaviour of MTs and therefore reduces MT polymerization $^{8}$, gatastatin failed to impair MT polymerization in vitro when this polymerization had been induced by either addition of glutamate $^{10}$, paclitaxel or recombinant Tau protein (Supplementary Fig. 3a-c). Moreover, gatastatin did not affect MT growth velocity as measured by total internal reflection fluorescence microscopy (TIRF) analysis of single MTs (Fig. 1b,c). In contrast, gatastatin blocked $\gamma$-TuSC-stimulated MT polymerization (Supplementary Fig. 3d) at the same concentration, as it was ineffective in blocking glutamate, paclitaxel and Tau-induced MT formation or affecting MT dynamics. Thus, gatastatin only affects $\gamma$-tubulin-dependent MT polymerization.

We previously reported that GTP binding of $\gamma$-tubulin is important for MT nucleation and viability of yeast cells ${ }^{14}$. We therefore tested the effect of gatastatin on GTP-binding activity of $\gamma$-tubulin in a $\alpha-\left[{ }^{32} \mathrm{P}\right]-\mathrm{GTP}$ crosslinking assay. Gatastatin inhibited GTP binding to human $\gamma$-tubulin (Table 2). Using the same assay, we showed that at an AG1 concentration that inhibits MT polymerization (Fig. 1b,c and Supplementary Fig. 3a-c), it failed to affect GTP-binding to $\gamma$-tubulin (Table 2). Because gatastatin did not affect paclitaxel-stimulated MT polymerization (Supplementary Fig. 3b), we also tested the impact of the drug on the binding of $\gamma$-TuSC to stabilize MTs. As shown in Fig. 1d, gatastatin impaired $\gamma$-TuSC binding to MT ends. Together, these data indicate that gatastatin is a specific inhibitor for $\gamma$-tubulindependent MT nucleation, while AG1 affects $\alpha / \beta$-tubulin without influencing $\gamma$-tubulin-stimulated MT formation.

To confirm the specificity of gatastatin towards $\gamma$-tubulindependent MT nucleation in a more physiological environment, we analysed MT formation in M-phase-arrested Xenopus egg extracts. Gatastatin strongly attenuated $\gamma$-tubulin-dependent, RanQ69Lstimulated aster formation $\left(\mathrm{IC}_{50}[\mathrm{RanQ69L}\right.$-aster $]=9.7 \mu \mathrm{M}$, Fig. 1e,f), but had no influence on dimethylsulphoxide (DMSO)stimulated, $\gamma$-tubulin-independent aster formation $\left(\mathrm{IC}_{50}[\mathrm{DMSO}-\right.$ aster $]=>100 \mu \mathrm{M}$, Fig. 1e,f). Quantitative analysis revealed that gatastatin reduced the radius and the MT density of RanQ69Ldependent asters without changing the number of asters (Fig. If and Supplementary Fig. 4d,e). Moreover, $\gamma$-tubulindependent, centrosome-induced aster formation was nearly 
a<smiles>COc1cc2c(=O)c(-c3cc(OC)c4c(c3OC)OCO4)coc2cc1OCc1ccccc1</smiles>

Gatastatin b
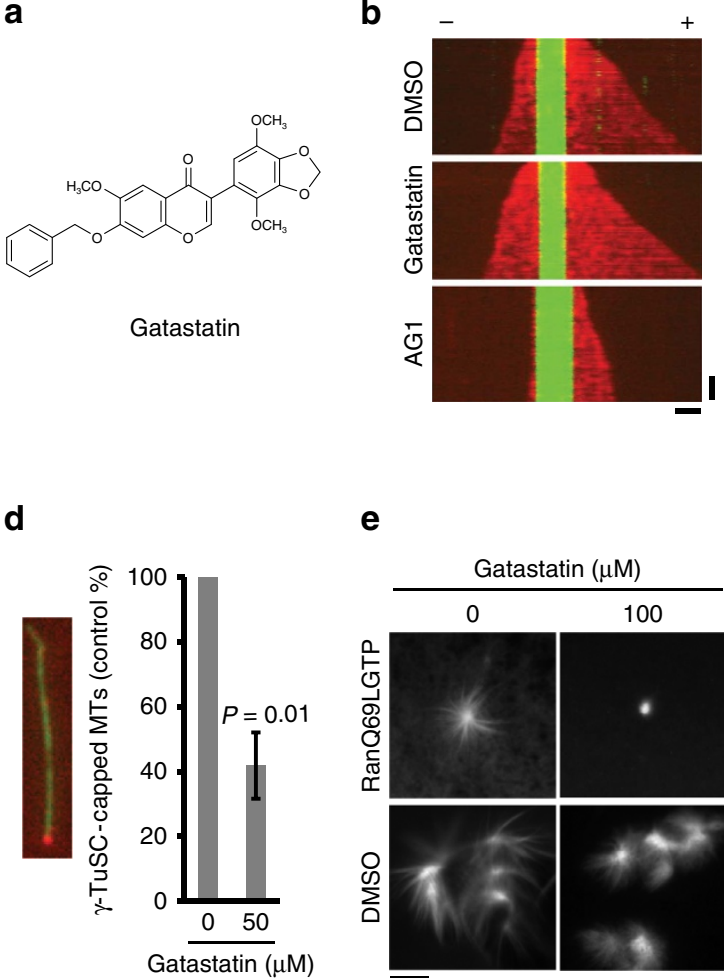

e

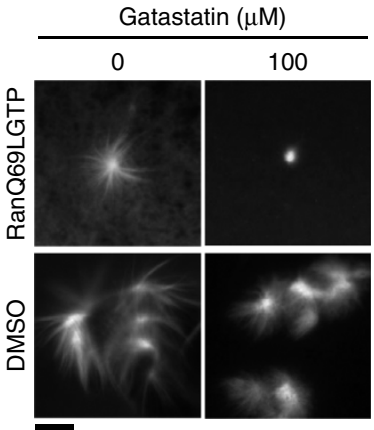

c



f

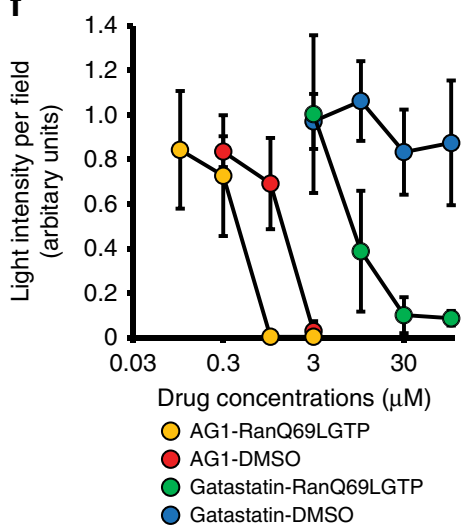

Figure 1 | Gatastatin is a $\boldsymbol{\gamma}$-tubulin-specific inhibitor. (a) The chemical structure of gatastatin. (b) The effect of gatastatin on MT dynamics in vitro was monitored as described in the Methods section. Kymographs of Alexa647-labelled MT polymerization (red) from tetramethylrhodamine- and biotinlabelled GMPCPP MT seeds (green) in the presence of GTP and either 1\% DMSO, $30 \mu$ gatastatin or $30 \mu M$ AG1. Horizontal scale bar, $2 \mu$ m; vertical scale bar, $1 \mathrm{~min}$. (c) Quantification of the compound's impact on the velocity of MT growth. Data are average velocities \pm s.e.m. calculated from 31 MTs (plus end) and 28 MTs (minus end) for DMSO, 23 MTs (plus end) and 22 MTs (minus end) for gatastatin, 23 MTs (plus end) and 20 MTs (minus end) for AG1. One-way ANOVA with Tukey's multiple comparisons test was used to determine the significance of the difference using the GraphPad Prizm 6 software. ${ }^{\star} P<0.0001$. There is no significant difference between the DMSO and gatastatin samples $(P>0.05)$. (d) The effect of gatastatin on the binding activity of $\gamma$-TuSC to paclitaxel-stabilized MTs. $\gamma$-TuSC was treated with $50 \mu \mathrm{M}$ of gatastatin and was incubated with paclitaxel-stabilized MTs. MTs and $\gamma$-TuSC were visualized by immunofluorescence on the coverslips using anti- $\alpha$-tubulin (green) and anti-His tag (red, $\gamma$-TuSC) antibodies, respectively. At least 440 MTs were counted in each experiment. Three independent experiments were performed. Error bars represent s.d. Two-tailed, paired Student's t-test was used to obtain $P$ value. (e) The effects of gatastatin on the RanQ69L- and DMSO-stimulated aster formation. Egg extracts with Cy3-tubulin and gatastatin were incubated for $20 \mathrm{~min}$ at $20^{\circ} \mathrm{C}$ in the presence of RanQ69L or $5 \%$ DMSO. Aster formation was analysed by fluorescence microscopy. Scale bar, $5 \mu$ m. (f) The average light intensity of asters in at least 10 randomly selected fields with a $\times 10$ objective was quantified. Three independent experiments were performed. Error bars represent s.d.

Table 2 | The effect of AG1 and gatastatin on GTP-binding activity of $\gamma$-tubulin in vitro.

\begin{tabular}{lcc} 
Compound & Concentration $(\boldsymbol{\mu} \mathbf{M})$ & GTP binding (control \%) \\
\hline AG1 & 60 & $93.7 \pm 11.7$ \\
Gatastatin & 60 & $6.7 \pm 3.7$
\end{tabular}

GTP-binding inhibition (control \%) by compounds was calculated as described in Methods section. Values are the mean \pm s.d.

completely inhibited by gatastatin (Supplementary Fig. 4f). In contrast, AG1 reduced the radius and MT density of both $\gamma$-tubulin-dependent (RanQ69L- and centrosome-induced) and $\gamma$-tubulin-independent (DMSO-induced) MT polymerization $\left(\mathrm{IC}_{50}[\right.$ RanQ69L-aster $]=0.44 \mu \mathrm{M}, \quad \mathrm{IC}_{50}[\mathrm{DMSO}$-aster $]=1.37 \mu \mathrm{M}$, Fig. If and Supplementary Fig. 4c-e,g). The ratio of the halfmaximal inhibitory concentration $\left(\mathrm{IC}_{50}\right)$ values confirmed that gatastatin specifically inhibits $\gamma$-tubulin-induced aster formation while AG1 is a general tubulin polymerization inhibitor (Fig. 1f; $\quad \mathrm{IC}_{50}[\mathrm{DMSO}$-aster $] / \mathrm{IC}_{50}[$ RanQ69L-aster $]=>10.4$ and 3.14 , respectively). In conclusion, gatastatin specifically inhibits $\gamma$-tubulin-induced MT assembly.

Gatastatin inhibits MT nucleation activity of centrosomes. $\gamma$-Tubulin localizes at centrosomes where it facilitates MT nucleation in interphase and mitosis ${ }^{6,15}$. To estimate whether gatastatin has the potential to inhibit $\gamma$-tubulin in human cells, we analysed the effect of gatastatin on $\gamma$-tubulin-dependent centrosomal MT nucleation activity. For this analysis, the MT network was first depolymerized either by nocodazole and cold treatment (interphase) or only cold treatment (mitosis). Subsequently, centrosome-organized MTs were allowed to re-grow by returning cells to permissive conditions. For MT regrowth analysis, we detected the plus TIP protein EB1 with antibodies. EB1 associates with growing MT plus tips ${ }^{16}$. On nocodazole washout/warming up of the cells, the EB1 and tubulin signals developed around interphase and mitotic centrosomes in 

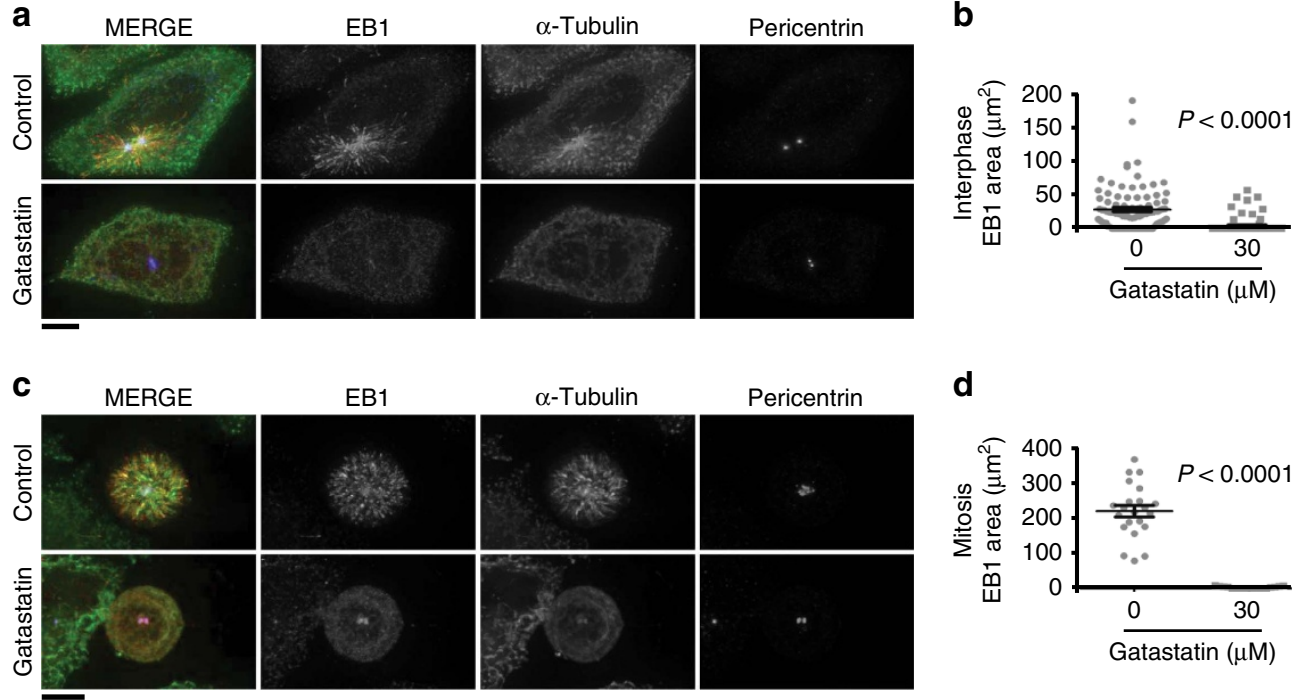

Figure 2 I Impact of gatastatin on MT regrowth in HeLa cells. (a) The impact of gatastatin on MT nucleation by centrosomes in interphase. After nocodazole and ice treatments, MT nucleation $\left(1 \mathrm{~min}\right.$ at $\left.37^{\circ} \mathrm{C}\right)$ in the presence of $30 \mu \mathrm{M}$ of gatastatin or the DMSO solvent control was monitored. Red, green and blue in the merged image represent EB1, $\alpha$-tubulin and pericentrin, respectively. Scale bar, $10 \mu \mathrm{m}$. Three independent experiments were performed and one representative experiment is shown. (b) The area of EB1 around centrosomes in a was calculated using the ImageJ software from 97 (control) or 84 (gatastatin) centrosomes. Error bars represent s.e.m. Two-tailed, unpaired Student's t-test was used to obtain $P$ value. (c) The impact of gatastatin on MT nucleation by centrosomes in mitosis. After STLC and ice treatments, spindle MT nucleation ( 1 min at $20^{\circ} \mathrm{C}$ ) in the presence of $30 \mu \mathrm{M}$ of gatastatin or the DMSO solvent control was monitored. Red, green and blue in merged image represent EB1, $\alpha$-tubulin and pericentrin, respectively. Scale bar, $10 \mu \mathrm{m}$. Three independent experiments were performed and one representative experiment is shown. (d) The area of EB1 around centrosomes in c was calculated using ImageJ software from 22 (control) or 17 (gatastatin) monopolar spindles. Error bars represent s.e.m. Two-tailed, unpaired Student's $t$-test was used to obtain $P$ value.

the control cells (Fig. 2a,c). This centrosome MT nucleation activity was $\gamma$-tubulin-dependent as it was reduced in cells with siRNA-depleted $\gamma$-tubulin (Supplementary Fig. 5a-f). Importantly, gatastatin inhibited MT nucleation activity of interphase and mitotic centrosomes of HeLa cells (Fig. 2a-d). Similar inhibition of $\gamma$-tubulin's MT nucleation activity by gatastatin was observed in RPE-1 and U2OS cells (Supplementary Figs 6 and 7). Interestingly, in both interphase and mitotic cells, $\gamma$-tubulin localization to centrosomes was not affected by gatastatin (Supplementary Fig. 8). Taken together, these results strongly suggest that gatastatin inhibits $\gamma$-tubulindependent MT nucleation of centrosomes in human cells without affecting $\gamma$-tubulin localization.

Gatastatin alters MT dynamics of interphase cells. Conditional lethal $\gamma$-tubulin mutations or siRNA depletion of $\gamma$-tubulin complex components affect MT dynamics and spindle assembly in yeast and Drosophila cells ${ }^{14,17-20}$. However, because siRNA depletion is slow, it is unclear whether this impact on MT dynamic changes is a direct consequence of $\gamma$-tubulin depletion. Furthermore, SAC activation by $\gamma$-tubulin depletion arrests cell cycle progression in prometaphase, making it difficult to draw firm conclusions about $\gamma$-tubulin functions in other mitotic phases. Gatastatin overcomes these limitations because of its rapid inhibition of $\gamma$-tubulin. We first ask whether a block to $\gamma$-tubulin function alters interphase MT dynamics. Gatastatin $(100 \mu \mathrm{M})$ addition did not obviously change the appearance of the interphase MT network in HeLa cells. The MT density was similar in DMSO control and $100 \mu \mathrm{M}$ gatastatintreated cells $2.5 \mathrm{~h}$ after drug addition (Fig. 3a). In contrast, addition of $30 \mu \mathrm{M}$ AG1 that binds to $\beta$-tubulin and inhibits MT dynamics $^{8}$ caused partial depolymerization of interphase MT network (Fig. 3a).
We next tracked EGFP-labelled EB3 to measure MT dynamics in interphase cells. EB3 is a plus TIP protein that specifically associates with the growing plus ends of $\mathrm{MTs}^{16}$. Gatastatin and AG1 (ref. 8) both decreased the average speed and track length of EB3 signal $15 \mathrm{~min}$ after drug addition to cells (Fig. $3 \mathrm{~b}$ and Table 3). However, in contrast to the clear reduction of the lifetime of EB3 at MT plus ends following AG1 treatment, gatastatin increased the lifetime of the EB3 signals (Table 3). Moreover, gatastatin did not affect the number of EB3 tracks. Thus, $\gamma$-tubulin inhibition by gatastatin reduces MT dynamics without affecting the number of growing MTs.

Gatastatin inhibits spindle formation but not mitotic entry. We analysed the consequences of gatastatin treatment on mitotic entry and spindle formation. HeLa cells were synchronized in the $S$ phase followed by treatment with either gatastatin or the solvent DMSO. The timing of mitotic entry was virtually identical in both cases (Fig. 3c,d). However, gatastatin impaired spindle formation as $\sim 80 \%$ of mitotic cells showed abnormal bipolar spindles with misaligned chromosomes (Fig. 3e). $\alpha$-Tubulin density was not markedly affected in these cells (Supplementary Fig. 9). Furthermore, the bipolar spindles of gatastatin-treated cells were shorter than those of control cells (Fig. 3g), and the SAC remained active as indicated by the BubR1 signal on kinetochores of misaligned chromosomes (Fig. $3 \mathrm{~h}$ ). Thus, $\gamma$-tubulin activity is needed for bipolar spindle formation.

Gatastatin reduces the length of metaphase spindles. An increase in $\gamma$-tubulin-dependent MT nucleation activity is required for spindle formation at the beginning of mitosis ${ }^{21}$. Whether $\gamma$-tubulin plays a role in mitosis beyond this step is, however, unclear. To assess the functions of $\gamma$-tubulin during mitosis, we arrested HeLa cells at defined mitotic phases, followed 
a

DMSO control



b DMSO control

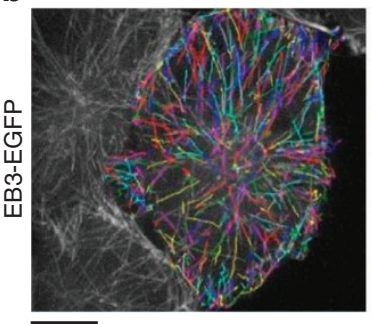

c



e
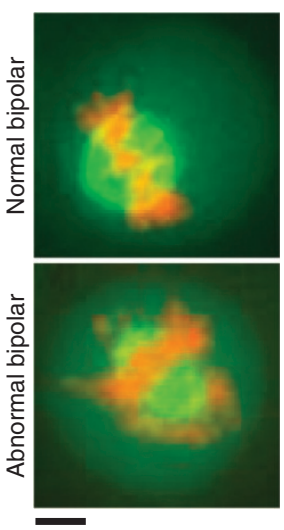

f

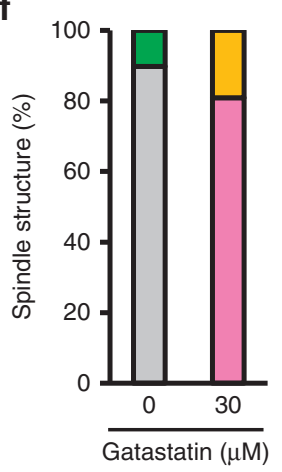

$\square$ Normal bipolar

$\square$ Multipolar

$\square$ Monopolar $\square$ Abnormal bipolar

AG1



AG1
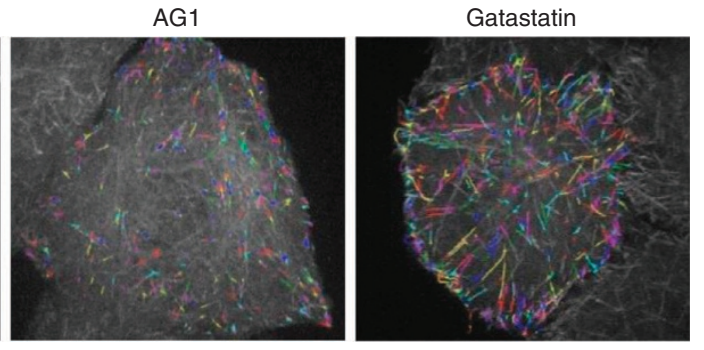

d

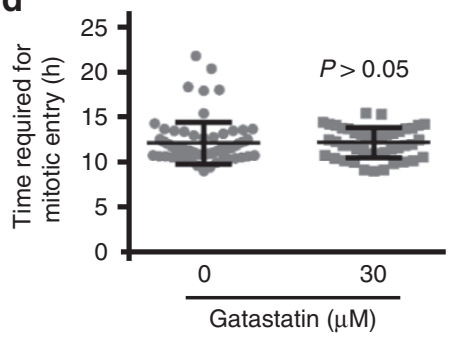

g



h

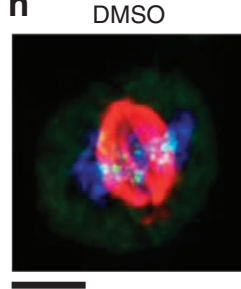

Gatastatin



Gatastatin

\section{列}


by addition of gatastatin. We first arrested cells in prometaphase using the reversible Eg5 inhibitor STLC followed by the addition of gatastatin and STLC washout (Fig. 4a). In the presence of gatastatin, $87 \%$ of cells were unable to assemble a metaphase-like spindle on STLC washout (Fig. 4b). In contrast, 55\% of control cells progressed through metaphase into anaphase, telophase and cytokinesis (Fig. 4b). Thus, $\gamma$-tubulin activity is required for the assembly of the metaphase spindle.
Next, we tested the impact of gatastatin on preformed metaphase-like spindles that were generated by MG132 inhibition of proteasome function after STLC washout (Fig. $4 \mathrm{c}-\mathrm{e})^{22}$. Gatastatin did not lead to metaphase spindle collapse (Supplementary Fig. 10). However, gatastatin reduced the length of the metaphase spindle by $22 \%$ compared with the control (Fig. 4d). In addition, imaging HeLa EB3-EGFP showed that gatastatin reduced the number of growing MTs by $17 \%$

Table 3 | Effects of AG1 and gatastatin on the MT dynamics in interphase cells.

\begin{tabular}{lccccc} 
Compound & Conc. $(\boldsymbol{\mu} \mathbf{M})$ & Velocity $\left(\boldsymbol{\mu} \mathbf{m} \mathbf{m i n}^{-\mathbf{1}}\right)$ & Track length $(\boldsymbol{\mu m})$ & Track lifetime $^{(\mathbf{s})}$ & Track numbers $^{\star}$ \\
\hline DMSO & & $12.70 \pm 1.65$ & $1.08 \pm 0.14$ & $3.32 \pm 0.55$ \\
AG1 & 1 & $9.59 \pm 1.01^{\star \star}$ & $0.73 \pm 0.09^{\star \star}$ & $3.30 \pm 0.57$ \\
& 3 & $7.33 \pm 1.23^{\star \star}$ & $0.43 \pm 0.07^{\star \star}$ & $2.20 \pm 0.67^{\star \star}$ & $106 \pm 30^{\star}$ \\
Gatastatin & 3 & $12.49 \pm 1.67$ & $1.03 \pm 0.16$ & $3.45 \pm 0.71$ & $94 \pm 27$ \\
& 10 & $10.03 \pm 0.99^{\star \star}$ & $0.84 \pm 0.10^{\star \star}$ & $3.67 \pm 0.62$ & $83 \pm 30$ \\
& 30 & $8.43 \pm 0.81^{\star \star}$ & $0.71 \pm 0.08^{\star \star}$ & $3.84 \pm 0.50^{\star}$ \\
\hline
\end{tabular}

Conc., concentration; DMSO, dimethylsulphoxide; MT, microtubule.

EB3-EGFP tracks from cells (Fig. 3b) were analysed as described in Methods section. Values are the mean \pm s.d. from 10,543 to 20,978 tracks from 20 to 35 cells ${ }^{*} P<0.05,{ }^{\star} * P<0.0001$. Two-tailed unpaired Student's $t$-test was used to obtain $P$ value by comparison with DMSO control.

${ }^{*}$ Track numbers from a $144-\mu \mathrm{m}^{2}$ area inside the cell were calculated as described in Methods section. Values are the mean \pm s.d. from 20 to 35 cells.
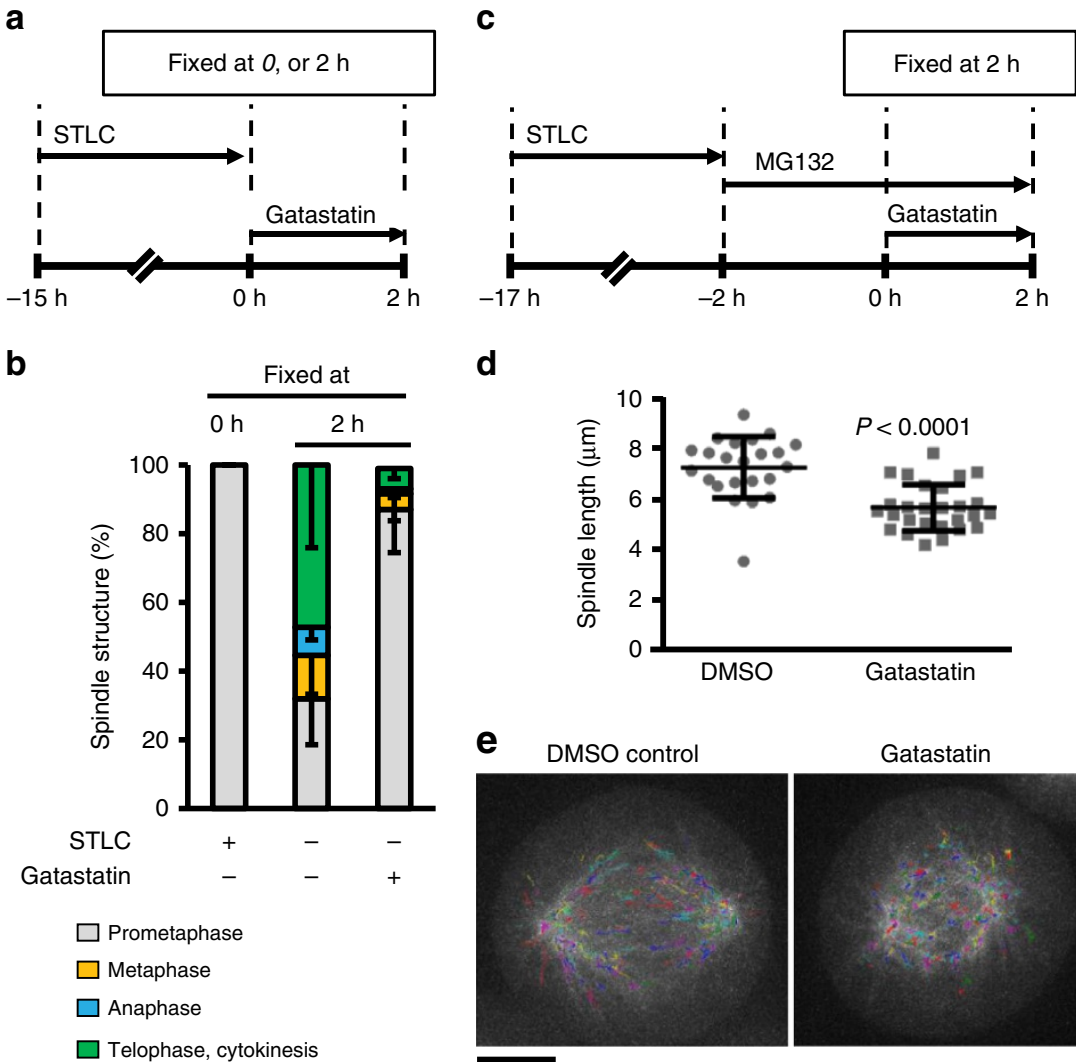

d
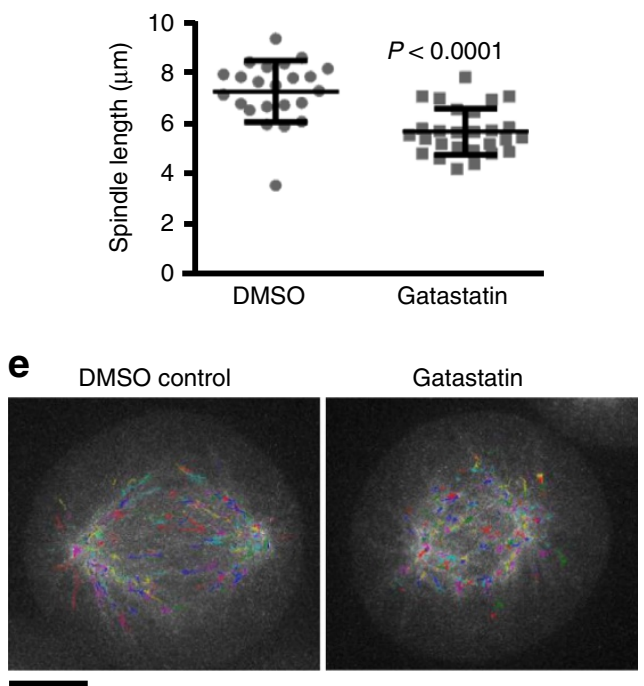

Figure 4 | Impact of gatastatin on mitotic spindle dynamics. (a,b) $\gamma$-Tubulin function is important for normal bipolar spindle formation. (a) Scheme of the experiment in $\mathbf{b}$. HeLa cells were arrested at prometaphase by treatment with $10 \mu \mathrm{M}$ of STLC for $15 \mathrm{~h}$ before STLC was washed out. Progression through mitotic phases was then monitored either in the presence or absence of $30 \mu \mathrm{M}$ of gatastatin for $2 \mathrm{~h}$. (b) The mitotic stages of 20 cells per experiment from the scheme in a were analysed in three independent experiments. Error bars represent s.d. (c-e) $\gamma$-Tubulin function is important for normal bipolar spindle maintenance. (c) Scheme of the experiment in d,e. After STLC washout, HeLa cells were arrested at metaphase with bipolar spindles by treatment with $5 \mu \mathrm{M}$ of MG132 for $2 \mathrm{~h}$. $30 \mu \mathrm{M}$ Gatastatin was added to cells and incubated for $2 \mathrm{~h}$ in the presence of MG132. (d) The spindle length (distance between centrosomes) of cells in scheme c was measured as described in Fig. $3 g$. Spindles of 20 cells per experiment were analysed. Three independent experiments were performed and one representative experiment is shown. Error bars represent s.d. Two-tailed, unpaired Student's $t$-test was used to obtain $P$ value. (e) The effect of gatastatin on spindle MT dynamics was analysed using HeLa cells expressing EB3-EGFP. EB3 signals of spindle in $\mathbf{c}$ were monitored. EB3 tracks are displayed in rainbow colours as maximum intensity projection of all time points from a 60 -s sequence of imaging. Scale bar, $5 \mu$ m. MT parameters are summarized in Table 4. 
(Fig. 4e and Table 4). We conclude that $\gamma$-tubulin activity is continually required for both spindle assembly in prometaphase and for maintaining the length and dynamicity of the metaphase spindle.

Gatastatin prolongs anaphase duration. We next measured the transit from metaphase to anaphase on MG132 washout with or without $\gamma$-tubulin inhibition (Fig. $5 \mathrm{a}-\mathrm{d}$ ). To overcome the inhibitory influence of the SAC that is triggered by altered MT dynamics, we incubated cells with the MPS1 kinase inhibitor reversine (Fig. 5a) ${ }^{23}$. Time-lapse analysis revealed that gatastatin increased anaphase duration from 18.6 to $32.4 \mathrm{~min}$ (Fig. 5b). The MTs in the anaphase spindle were less focused than in control cells (Fig. $5 c, d$ ). Midzone MT bundles formed in gatastatin-treated cells (Fig. 5c,d, $30-45 \mathrm{~min}$ ) but were less focused and organized compared with the control. However, this disorganized midzone recruited the cytokinesis marker CEP55 (ref. 24; Supplementary Fig. 11) and promoted actin ring assembly (Supplementary Fig. 12), indicating that it retained functions. Thus, $\gamma$-tubulin activity is required not only for metaphase spindle assembly and maintenance but also for anaphase spindle elongation.

\section{Discussion}

Our study has identified gatastatin as the inhibitor of $\gamma$-tubulin that blocks GTP binding to $\gamma$-tubulin and $\gamma$-tubulin's MT nucleation activity. Several lines of evidence support the notion that gatastatin specifically inhibits $\gamma$-tubulin without affecting $\alpha / \beta$-tubulin. First, gatastatin showed a 12 -fold higher affinity towards $\gamma$-tubulin in comparison with $\alpha / \beta$-tubulin (Table 1 ). Second, gatastatin did not affect glutamate, paclitaxel or Tau-induced MT assembly in vitro

Table 4 | Effects of gatastatin on the MT dynamics in mitotic cells.

\begin{tabular}{lccccc} 
Compound & Conc. $(\boldsymbol{\mu M})$ & Velocity $\left(\boldsymbol{\mu} \mathbf{m} \mathbf{~ m i n}^{-1}\right)$ & Track length $(\boldsymbol{\mu m})$ & Track lifetime $(\mathbf{s})^{\text {Track numbers }^{\star}}$ \\
\hline DMSO & \multirow{3}{*}{30} & $13.35 \pm 0.92$ & $0.67 \pm 0.09$ & $1.64 \pm 0.42$ & $44.67 \pm 7.07$ \\
Gatastatin & $11.21 \pm 1.68^{\star \star}$ & $0.53 \pm 0.09^{\star \star}$ & $1.76 \pm 0.66$ \\
\hline
\end{tabular}

Conc., concentration; DMSO, dimethylsulphoxide; MT, microtubule.

EB3-EGFP tracks from mitotic cells of Fig. 4 e condition were analysed as described in Methods section. Values are the mean \pm s.d. from 9,146 to 11,403 tracks from 15 to 18 cells from three independent experiments ${ }^{* \star} P<0.0001$. Two-tailed, unpaired Student's $t$-test was used to obtain $P$ value by comparison with DMSO control.

*Track numbers from a $25-\mu \mathrm{m}^{2}$ area in the spindle were calculated as described in Methods section. Values are the mean \pm s.d. from 15 to 18 cells.

a



b

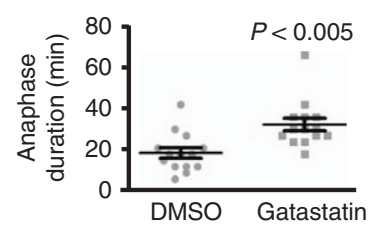

d



C Control $(\mathrm{min})$


Figure 5 | Impact of gatastatin on anaphase spindle elongation. $\gamma$-Tubulin function is important for the anaphase progression. (a) Scheme of the experiment in b-d. After washout of MG132 from $30 \mu \mathrm{M}$ gatastatin-treated metaphase cells, the transition into anaphase, telophase or cytokinesis was observed in the presence of reversine. (b) Anaphase duration in a was analysed from 14 cells with a $\times 40$ objective. Error bars represent s.e.m. Two-tailed, unpaired Student's t-test was used to obtain $P$ value. Three independent experiments were performed and one representative data set is shown. (c) Anaphase spindle and midzone structure of HeLa cells expressing mCherry-H2B and EGFP- $\alpha$-tubulin in the presence of $1 \%$ DMSO or $30 \mu \mathrm{M}$ gatastatin was observed with a $\times 60$ objective. Green and orange represent $\alpha$-tubulin and DNA, respectively. Arrowheads and arrows represent anaphase spindle and midzone, respectively. Scale bar, $5 \mu \mathrm{m}$. (d) The anaphase spindle and midzone structures in $\mathbf{b}$ were categorized into two patterns as shown in c. 
while $\gamma$-TuSC-induced MT assembly was inhibited (Supplementary Fig. 3). Third, gatastatin did not affect dynamics of MTs in vitro (Fig. 1b,c). Forth, gatastatin blocked binding of $\gamma$-TuSC to the minus end of preformed MTs (Fig. 1d). Fifth, gatastatin inhibited $\gamma$-tubulin-dependent MT nucleation in Xenopus egg extracts while DMSO-induced MT assembly was unaffected (Fig. 1e,f). Finally, gatastatin blocked $\gamma$-tubulin-dependent MT nucleation activity of centrosomes in human cells (Fig. 2). Together, these experiments provide a strong case for the $\gamma$-tubulin specificity of gatatastin. However, we cannot exclude the possibility that gatastatin at higher concentrations affects MTs directly.

What is the mode of action of gatastatin? Gatastatin did not misplace $\gamma$-tubulin from centrosomes (Supplementary Fig. 8). Thus, it is unlikely that it inhibits Nedd1-dependent recruitment processes ${ }^{15}$. Since GTP binding to yeast $\gamma$-tubulin regulates the interaction of $\gamma$-tubulin with $\alpha / \beta$-tubulin ${ }^{14}$, we suggest that this critical step in MT nucleation is blocked by gatastatin. However, as for paclitaxel that modifies intrinsic MT properties by targeting tubulin, gatastatin probably modulates $\gamma$-tubulin activity without invoking a complete inhibition. This view is supported by the observation that gatastatin did not completely inhibit RanQ69Linduced aster formation (Fig. 1e,f).

When used to unravel novel functions of $\gamma$-tubulin during the cell cycle, gatastatin highlights the importance of $\gamma$-tubulin in the regulation of MT plus end dynamics during interphase and in preassembled metaphase spindles. Consistent with this observation, changes in MT dynamics in response to $\gamma$-TuRC components' depletion or mutations in $\gamma$-TuSC components have been reported in Drosophila S2 cells, S. pombe and budding yeast $S$. cerevisiae $e^{14,20,25}$. How $\gamma$-tubulin regulates MT plus end dynamics is still unclear. One attractive possibility is that the $\gamma$-tubulin complex at the MT minus end ${ }^{1}$ superimposes a structural change on the MT lattice that is propagated along the length of the MT wall to alter the structure and thus dynamics of the remote plus end.

In preassembled metaphase spindles after $\gamma$-tubulin inhibition, the pole-kinetochore and pole-pole MTs were not fully functional, as indicated by the persistent activation of the SAC, the reduced number of growing MTs and the reduced spindle length. Thus, $\gamma$-tubulin activity is not only needed to assemble the mitotic spindle as this was already indicated by $\gamma$-tubulin siRNA depletion analysis ${ }^{26}$ but also to maintain a functional metaphase spindle. A recent study has shown that $\gamma$-TuRC actively contributes to spindle architecture by organizing MT minus ends that originate within the main body of the spindle before being transported to the spindle poles ${ }^{27}$.

$\gamma$-Tubulin activity was also important for anaphase spindle elongation (Fig. 5). In the presence of gatastatin, the anaphase spindle was much broader and spindle MTs were less organized into parallel bundles of MTs than in the control. Consistent with these defects, gatastatin increased anaphase duration from 18.6 to $32.4 \mathrm{~min}$. Presently, it is unclear whether this anaphase activity of $\gamma$-tubulin resides at centrosomes or is bound to MTs via the augmin complex.

During ingression of the cleavage furrow, the MTs of the central spindle become compacted to form the midbody. In the presence of gatastatin, midbody MTs were less organized but still were able to recruit the cytokinesis marker CEP55 (ref. 24) and to induce actin ring assembly (Supplementary Figs 11 and 12). This observation is consistent with the localization of $\gamma$-tubulin to the midbody and the finding that $\gamma$-tubulin antibody micro-injection experiments disturbed midbody formation without inhibition of cytokinesis $^{28}$.

$\gamma$-Tubulin is overexpressed in glioblastoma cells ${ }^{29}$. Furthermore, elevated MT nucleation activity from centrosomes enhances the invasiveness of cancer cells ${ }^{30}$. Reversing the elevated nucleation capacity of centrosomes through $\gamma$-tubulin inhibition may offer one route to reduce the aggressiveness and metastatic potential of the wide range of tumour cells in which centrosomes are amplified. Our proof-of-principle study showing that chemical modifications of known $\alpha / \beta$-tubulin inhibitors can switch target specificity towards $\gamma$-tubulin is therefore an exciting new avenue for the development of novel cancer therapeutics.

\section{Methods}

Chemical and regents. Colchicine and nocodazole were purchased from Sigma. Plinabulin and AG1 were synthesized as described ${ }^{9,10}$. KPU-406 was synthesized as described in the Supplementary Note 1 and Supplementary Figs 13-15. Gatastatin $\left(O^{7}\right.$-demethylbenzyl AG1) was synthesized by a more efficient synthetic method (Supplementary Note 2). All chemicals were dissolved in DMSO.

Expression and purification of tubulins and $\gamma$-TuSC. The human $\gamma$-tubulin-myc6 His was expressed in Sf 21 insect cells. In brief, $0.7 \times 10^{6} \mathrm{cells} \mathrm{ml}^{-1}$ were infected with the $\gamma$-tubulin baculovirus. After $48 \mathrm{~h}$, cells were collected by centrifugation at $1,0000 \mathrm{~g}$ for $10 \mathrm{~min}$ and flash-frozen in liquid nitrogen and stored at $-80^{\circ} \mathrm{C}$. Purification was carried out as described with slight modifications ${ }^{11}$. Cells were disrupted in lysis buffer $\left(50 \mathrm{mM} \mathrm{KPO}_{4} \mathrm{pH} 8.0,500 \mathrm{mM} \mathrm{KCl}, 1 \mathrm{mM} \mathrm{MgCl}\right.$, $10 \%$ glycerol, $10 \mu \mathrm{M}$ GTP, $1 \mathrm{mM}$ dithiothreitol (DTT)) supplemented with protease inhibitor cocktail (Roche, \#11 873580001 ) and centrifuged at $11,950 \mathrm{~g}$ for $10 \mathrm{~min}$ at $4{ }^{\circ} \mathrm{C}$. Imidazole (final $10 \mathrm{mM}$ ) was added and the lysate was centrifuged again at $192,800 \mathrm{~g}$ for $30 \mathrm{~min}$ at $4^{\circ} \mathrm{C}$. Ni-NTA Agarose (QIAGEN, \#1018240) was added to the supernatant and incubated for $1 \mathrm{~h}$ at $4{ }^{\circ} \mathrm{C}$. Ni-NTA Agarose was then washed twice with wash buffer 1 (lysis buffer containing $25 \mathrm{mM}$ imidazole) and wash buffer 2 (50 mM MES pH 6.6, $500 \mathrm{mM} \mathrm{KCl,} 5 \mathrm{mM} \mathrm{MgCl}_{2}, 10 \%$ glycerol, $10 \mu \mathrm{M}$ GTP and $1 \mathrm{mM}$ DTT) containing $25 \mathrm{mM}$ imidazole. $\gamma$-Tubulin was eluted with wash buffer 2 containing $200 \mathrm{mM}$ imidazole.

Monomeric $\gamma$-tubulin was prepared using a size exclusion column HiLoad 16/ 60 Superdex 200 pre-equilibrated with gel filtration buffer ( $50 \mathrm{mM} \mathrm{MES} \mathrm{pH} \mathrm{6.6,}$ $500 \mathrm{mM} \mathrm{KCl}, 5 \mathrm{mM} \mathrm{MgCl} 2,1 \mathrm{mM}$ EGTA, $10 \mu \mathrm{M}$ GTP and $1 \mathrm{mM}$ DTT). The peak fractions representing monomeric $\gamma$-tubulin were identified by $\mathrm{A}_{280}$ and confirmed using SDS-PAGE. Protein was concentrated using a Vivaspin concentrator (Sartorius) and supplemented with $10 \%$ glycerol, following snap-freezing in liquid nitrogen and storage at $-80^{\circ} \mathrm{C}$.

$\gamma$-TuSC was purified as described ${ }^{14,31}$. Briefly, $\gamma$-TuSC was expressed in HighFive cells and purified by sequential steps of Ni-NTA (Macherei-Nagel) purification, MonoQ column purification (GE Healthcare) and size exclusion (Superdex 200 column, GE Healthcare) ${ }^{14}$. $\alpha / \beta$-Tubulin was purified from porcine brain through four cycles of polymerization and depolymerization using $1 \mathrm{M}$ PIPES buffer (1 M PIPES-KOH, $1 \mathrm{mM}$ EGTA, $1 \mathrm{mM} \mathrm{MgCl}_{2}$, pH 6.8) for effective removal of MT-associated proteins ${ }^{32}$.

Purification of GCP4 and Tau recombinant proteins. For expression and purification of full-length GCP4, pET26(+)-GCP4-His ${ }_{6}$ was transformed into Escherichia coli strain BL21-CodonPlus. GCP4 was expressed and purified as described with slight modifications ${ }^{12}$.

Cells were cultured in LB medium containing $50 \mu \mathrm{g} \mathrm{ml}^{-1}$ kanamycin and $30 \mu \mathrm{g} \mathrm{ml}^{-1}$ chloramphenicol at $37^{\circ} \mathrm{C}$ until the $\mathrm{OD}_{600}$ was $\sim 0.5$. Final concentrations of $0.4 \mathrm{mM}$ isopropyl $\beta$-D-thiogalactopyranoside was added and protein expression was induced at $25^{\circ} \mathrm{C}$ for $6 \mathrm{~h}$. Cells were harvested by centrifuging at $20,000 \mathrm{~g}$ for $20 \mathrm{~min}$ at $4{ }^{\circ} \mathrm{C}$ and resuspended in lysis buffer $(50 \mathrm{mM}$ sodium phosphate $\mathrm{pH} 8.0,300 \mathrm{mM} \mathrm{NaCl}, 10 \mathrm{mM}$ imidazole, $5 \%$ glycerol, $1 \mathrm{mM}$ phenylmethyl sulphonyl fluoride (PMSF) and protease inhibitor cocktail (Roche, \#11 873580001$)$ ). Cells were disrupted by sonication on ice and were centrifuged at $20,000 \mathrm{~g}$ for $40 \mathrm{~min}$ at $4{ }^{\circ} \mathrm{C}$. Ni-NTA Agarose (QIAGEN, \#1018240) and same volume of phosphate buffer $(50 \mathrm{mM}$ sodium phosphate $\mathrm{pH} 8.0,150 \mathrm{mM} \mathrm{NaCl}$, $5 \%$ glycerol and $2.5 \mathrm{mM}$ DTT) containing $10 \mathrm{mM}$ imidazole were mixed with supernatant and incubated for $1 \mathrm{~h}$ at $4{ }^{\circ} \mathrm{C}$. The agarose beads were washed twice with phosphate buffer. GCP4 was eluted with $1 \mathrm{ml}$ of phosphate buffer containing $150 \mathrm{mM}$ imidazole.

Monomeric GCP4 was prepared using the size exclusion column HiLoad 16/60 Superdex 200 pre-equilibrated with gel filtration buffer $(20 \mathrm{mM}$ Tris- $\mathrm{HCl}, \mathrm{pH} 8.0$, $150 \mathrm{mM} \mathrm{NaCl}$ and $2 \mathrm{mM}$ DTT). The peak fractions representing monomeric GCP4 were concentrated using a Vivaspin concentrator (Sartorius), following snap-freezing in liquid nitrogen and storage at $-80^{\circ} \mathrm{C}$.

For expression and purification of full-length Tau protein, GST-Tau expression plasmid (pTU499) was constructed. Full-length Tau fragment was amplified from pRK174-Tau ${ }^{33}$ using primers $5^{\prime}$-cgGGATCCatggctgagcccegccaggagt- $3^{\prime}$ and $5^{\prime}$-ccGAATTCatcacaaacctgcttggccag- $3^{\prime}$ containing BamHI and EcoRI sites (underlined), respectively. The Tau fragment was digested with BamHI and EcoRI and ligated into BamHI and EcoRI sites of the E. coli expressing vector pGEX-6P-2. The constructed plasmid, pTU499, was transformed into E. coli strain BL21. Cells were cultured in LB medium containing $100 \mu \mathrm{g} \mathrm{ml}^{-1}$ ampicillin at $37^{\circ} \mathrm{C}$ until the $\mathrm{OD}_{600}$ was $\sim 0.4$. Final concentrations of $0.5 \mathrm{mM}$ isopropyl $\beta$-D-

thiogalactopyranoside was added and protein expression was induced at $37^{\circ} \mathrm{C}$ for 
$6 \mathrm{~h}$. Cells were harvested by centrifuging at $20,000 \mathrm{~g}$ for $10 \mathrm{~min}$ at $4{ }^{\circ} \mathrm{C}$ and were resuspended in lysis buffer $(1 \times$ PBS containing protease inhibitors $(2 \mathrm{mM}$ PMSF and $5 \mathrm{mM}$ benzamidine) and $0.1 \%$ Triton X-100). Cells were disrupted by sonication on ice and were centrifuged at $20,000 \mathrm{~g}$ for $20 \mathrm{~min}$ at $4{ }^{\circ} \mathrm{C}$. Glutathioneagarose beads (Amersham Biosciences, Cat\# 27-4574-01) and final concentrations of $1 \mathrm{mM}$ ATP were added to supernatant and incubated for $1 \mathrm{~h}$ at $4{ }^{\circ} \mathrm{C}$. The agarose beads were washed three times with RB buffer (100 mM MES, pH 6.8, $0.5 \mathrm{mM}$ $\mathrm{MgCl}_{2}$ and $1 \mathrm{mM} \mathrm{EGTA}$ ) containing $1 \mathrm{mM}$ ATP. GST-fusion proteins were eluted with $2 \mathrm{ml}$ of RB buffer containing $30 \mathrm{mM}$ glutathione. Glutathione was removed using 10 DG desalting column (Bio-Rad).

Tryptophan-based drug-binding assay. Gel filtration buffer for $\gamma$-tubulin purification (50 mM MES pH 6.6, $500 \mathrm{mM} \mathrm{KCl}, 5 \mathrm{mM} \mathrm{MgCl}_{2}, 1 \mathrm{mM}$ EGTA and $1 \mathrm{mM}$ DTT) supplemented with $10 \%$ of glycerol was used as an assay buffer. $\gamma$-tubulin and $\alpha / \beta$-tubulin were diluted in this assay buffer to reach a final protein concentration of $1 \mu \mathrm{M}$. A final concentration of $10 \mu \mathrm{M}$ or $1 \mathrm{mM}$ GTP was added to the samples. Proteins were incubated for $30 \mathrm{~min}$ with compounds (final DMSO concentration was $1 \% ; 2 \%$ for AG1 and gatastatin). After incubation, tryptophan fluorescence of the protein was monitored at $295 \mathrm{~nm}$ (excitation) and the scan range was $310-450 \mathrm{~nm}$ (emission) using JASCO Spectrofluorometer FP-6500. Dissociation constants were calculated from fitting curves of decreasing fluorescence $(\Delta \mathrm{FL})$ using the GraphPad Prizm software.

Inhibition of GTP binding of $\gamma$-tubulin. For analysis of the effect of drugs on GTP binding of $\gamma$-tubulin, $70 \mathrm{nM}$ of purified human $\gamma$-tubulin in GTP-binding buffer (50 mM MES, $5 \mathrm{mM} \mathrm{MgCl}_{2}, 1 \mathrm{mM}$ EGTA, pH 6.6) was incubated with or without compounds for $15 \mathrm{~min}$ at $20^{\circ} \mathrm{C}$. A final concentration of $100 \mathrm{nM}$ of $\alpha-\left[{ }^{32} \mathrm{P}\right]-\mathrm{GTP}$ was added and incubated at $20^{\circ} \mathrm{C}$ for $30 \mathrm{~min}$. After incubation, bound $\alpha-\left[{ }^{32} \mathrm{P}\right]-$ GTP was crosslinked to $\gamma$-tubulin for $60 \mathrm{~s}$ by illumination with a ultraviolet lamp using CL-1000 Ultraviolet Crosslinker. Protein with the crosslinked GTP was separated from unbound nucleotide by TCA precipitation and SDS-PAGE, and ${ }^{32} \mathrm{P}$ labelling was measured using a Typhoon FLA-7000 (General Electronic Company). Band intensities were quantified with the ImageJ software.

Measurement of MT dynamics in vitro. Purified $\alpha / \beta$-tubulin was labelled with tetramethylrhodamine Succinimidyl Ester (C-1171, Life Technologies), Alexa Fluor 647 NHS Ester (A-20106, Life Technologies) or NHS-LC-biotin (21336, Life Technologies) as described ${ }^{34}$. Briefly, $\alpha / \beta$-tubulin was polymerized to form MTs. Then, the MTs were centrifuged, resuspended in labelling buffer containing NHSconjugated dye or biotin. After the labelling reaction, two cycles of polymerization and depolymerization were performed to obtain active $\alpha / \beta$-tubulin.

GMPCPP MT seeds were prepared by copolymerization of non-labelled tubulin, tetramethylrhodamine-labelled tubulin and biotin-labelled tubulin with $0.2 \mathrm{mM}$ GMPCPP to yield the rhodamine and biotin labelling ratio $2 \%$ and $3 \%$, respectively. GMPCPP was prepared enzymatically from GMPCP (M3170, SigmaAldrich) and nucleotide diphosphate kinase (N0379, Sigma-Aldrich) ${ }^{35}$. The glass chambers for observation were prepared as follows. Surface of cover glasses (C022221S, Matsunami Glass) was cleaned by sonication in $1 \mathrm{~N} \mathrm{KOH}$ and by plasma treatment (Diener), and then silanized with N-2-(aminoethyl)-3aminopropyl-triethoxysilane (KBE-603, Shin-Etsu Chemical). The amino-silanized glasses were incubated with $200 \mathrm{mg} \mathrm{ml}^{-1}$ NHS-PEG (ME-050-TS, NOF) with and without $1 \mathrm{mg} \mathrm{ml}^{-1}$ NHS-PEG-biotin (BI-050-TS, NOF) for $3 \mathrm{~h}$ at room temperature to make PEG-biotin-coated and PEG-coated glasses ${ }^{36}$. The PEGbiotin-coated glass and the PEG-coated glass were separated using a $30-\mu \mathrm{m}$ layer of double sticking tape (5603, Nitto-Denko) to make the flow chamber. The MTs were immobilized on the PEG-biotin-coated glass surface via Neutravidin (31000, Thermo), and then the glass surface was blocked with imaging solution $(100 \mathrm{mM}$ PIPES-KOH, $2 \mathrm{mM} \mathrm{MgSO}_{4}$, 1 mM EGTA, $1 \mathrm{mM}$ GTP, 1\% (w/v) Pluronic F-127, $1 \mathrm{mg} \mathrm{ml}^{-1}$ casein, $1 \mathrm{mM}$ D-biotin, $2 \mathrm{mM}$ dithiothreitol, $0.2 \mathrm{mg} \mathrm{ml}^{-1}$ glucose oxidase, $40 \mu \mathrm{g} \mathrm{ml}^{-1}$ catalase, $1 \mathrm{mM}$ glucose, $0.05 \%$ (v/v) methylcellulose, $\mathrm{pH}$ 6.9). Finally, $5 \mu \mathrm{M}$ tubulin containing $100 \mathrm{nM}$ Alexa Fluor 647-labelled tubulin and $1 \%$ (v/v) DMSO, $30 \mu \mathrm{M}$ Gatastatin or $30 \mu \mathrm{M}$ AG1 were added to the imaging solution and introduced into the chamber. The images of MTs were observed under total internal reflection fluorescence microscopy (IX81, Olympus) with a $\times 100$ objective lens (UPlanSApo, numerical aperture (NA) 1.40, Olympus) and recorded at the frame rate of two frames per second using iXon3 EM CCD camera (Andor). Each MT image was rotated and translated to align the GMPCPP seed in the rhodamine channel by using custom scripts on the Fiji distribution of Image J (ref. 37). Then, the kymograph was generated to measure the dynamics of MT growth.

In vitro MT polymerization assay. For glutamate-stimulated MT polymerization, $1 \mathrm{mg} \mathrm{ml}^{-1}$ porcine brain $\alpha / \beta$-tubulin was mixed with glutamate (final concentration $1 \mathrm{M}$ ) and GTP (final concentration $1 \mathrm{mM}$ ) in RB buffer on ice. For paclitaxel-stimulated MT polymerization, $1 \mathrm{mg} \mathrm{ml}^{-1}$ porcine brain $\alpha / \beta$-tubulin was mixed with paclitaxel (final concentration $10 \mu \mathrm{M}$ ) and GTP (final concentration $1 \mathrm{mM}$ ) in RB buffer on ice. For recombinant Tau protein-stimulated MT polymerization, $1 \mathrm{mg} \mathrm{ml}^{-1} \alpha / \beta$-tubulin purified from porcine brain and Tau protein were mixed with GTP (final concentration $1 \mathrm{mM}$ ) in RB buffer on ice. For $\gamma$-TuSC-stimulated MT polymerization, $\gamma$-TuSC was mixed with GTP (final concentration $1 \mathrm{mM}$ ). One of the compounds and $\alpha / \beta$-tubulin were then added. Samples were transferred into cuvettes. Tubulin polymerization was monitored using the absorbance at $350 \mathrm{~nm}$ at $37^{\circ} \mathrm{C}$ using a thermostatic spectrophotometer (Beckman Coulter).

$\gamma$-TuSC capping to paclitaxel stabilized MT analysis. $\gamma$-TuSC was diluted in RB buffer containing $10 \mu \mathrm{M}$ paclitaxel to reach a final protein concentration of $0.5 \mu \mathrm{M}$ and incubated with $50 \mu \mathrm{M}$ of gatastatin for $30 \mathrm{~min}$ at $25^{\circ} \mathrm{C}$. Polymerized MTs were prepared by incubation of $\sim 5 \mathrm{mg} \mathrm{ml}^{-1} \alpha / \beta$-tubulin for $30 \mathrm{~min}$ at $37^{\circ} \mathrm{C}$ with $1 \mathrm{mM}$ GTP; then paclitaxel was added (final $10 \mu \mathrm{M}$ ). GTP was removed from paclitaxel-stabilized MTs with ultracentrifugation at $240,000 \mathrm{~g}$ for $10 \mathrm{~min}$ at $25^{\circ} \mathrm{C}$. Paclitaxel-stabilized MTs were added to $\gamma$-TuSC (final $\sim 1.2 \mathrm{mg} \mathrm{ml}^{-1}$ ). Next, $\gamma$-TuSC was incubated with paclitaxel-stabilized MTs for $30 \mathrm{~min}$; MTs and MT-bound $\gamma$-TuSC were collected with ultracentrifugation at $240,000 \mathrm{~g}$ for $10 \mathrm{~min}$ at $25^{\circ} \mathrm{C}$ and finally placed on poly-L-lysine-coated coverslips. After incubation for 15 min, coverslips were immediately fixed with cold $\mathrm{MeOH}\left(-20^{\circ} \mathrm{C}\right)$. Coverslips were blocked with PBS containing $0.5 \%$ bovine serum albumin and were incubated with anti- $\alpha$-tubulin (1:200 dilution, MBL, Cat\# PM054) and anti-penta His (1:200 dilution, Qiagen, Cat\# 34660) antibodies. After staining with Alexa ${ }^{488}$-conjugated anti-rabbit IgG (1:2000 dilution, Invitrogen) and Alexa ${ }^{568}$-conjugated anti-mouse IgG (1:2000 dilution, Invitrogen), the coverslips were washed four times with PBS and mounted with PBS. $\gamma$-TuSC bound to MTs was observed under a LAS AF 6000 fluorescence microscope (Leica Microsystems, Wetzlar, Germany).

Xenopus egg extract analysis. Cytostatic factor (CSF)-arrested M phase Xenopus egg extracts (CSF extracts) were prepared ${ }^{38}$. Briefly, unfertilized eggs were crushed by $10,700 \mathrm{~g}$ centrifugation for $20 \mathrm{~min}$. M phase extracts were mixed with $0.5 \mu \mathrm{M}$ Cy3-labelled $\alpha / \beta$-tubulin and various concentrations of compounds. After incubation for $30 \mathrm{~min}$ on ice, $15 \mu \mathrm{M}$ RanQ69L, 200 sperm nuclei per $\mu \mathrm{l}$ or $5 \%$ DMSO were added and incubated for $30 \mathrm{~min}$ on ice. After incubation for $20 \mathrm{~min}$ at $20^{\circ} \mathrm{C}$ (for the samples with sperm nuclei, the incubation time was $30 \mathrm{~min}$ ), $1.5 \mu \mathrm{l}$ sample was fixed with $1.5 \mu \mathrm{l}$ fix solution ( 0.3 volume of $37 \%$ formaldehyde, 0.6 volume of $80 \%$ glycerol and 0.1 vol of $10 \times$ MMR solution (50 mM HEPES, $\mathrm{pH} 7.8$, $1 \mathrm{M} \mathrm{NaCl}, 20 \mathrm{mM} \mathrm{KCl}, 10 \mathrm{mM} \mathrm{MgCl}_{2}, 20 \mathrm{mM} \mathrm{CaCl}_{2}$ and $\left.1 \mathrm{mM} \mathrm{EDTA}\right)$ ), followed by the squash fix.

For $\gamma$-tubulin depletion, freshly prepared egg extracts were incubated for $30 \mathrm{~min}$ with $\gamma$-tubulin antibodies coupled to Dynabeads Protein A (Thermo Fisher Scientific) three times ${ }^{39,40}$. The depletion efficiency was verified using western blot analysis.

Images were acquired using a microscope (Axiovert $200 \mathrm{M}$; Carl Zeiss Inc.) equipped with a plan-Apochromat $\times 63$ NA 1.3 oil objective lens (Carl Zeiss Inc.), a Cy3 emission filter and a Cascade: $1 \mathrm{~K}$ (Photometrics Inc.) camera, and the AxioVision software (Carl Zeiss Inc.). The aster size and fluorescence intensity were quantified using a macro written in MATLAB ${ }^{41}$.

\section{MT nucleation assay. HeLa and U2OS cells were cultured in DMEM +} GlutaMAX (Gibco) supplemented with $10 \%$ fetal bovine serum (FBS), $100 \mathrm{U} \mathrm{ml}^{-1}$ penicillin, $100 \mu \mathrm{g} \mathrm{ml}^{-1}$ streptomycin and $1 \mathrm{mM}$ sodium pyruvate in a humidified atmosphere containing $5 \% \mathrm{CO}_{2}$. RPE-1 cells were cultured in DMEM/F-12 (Gibco) supplemented with $10 \% \mathrm{FBS}, 2 \mathrm{mM}$ L-glutamine, $100 \mathrm{U} \mathrm{ml}^{-1}$ penicillin, $100 \mu \mathrm{g} \mathrm{ml}^{-1}$ streptomycin, $1 \mathrm{mM}$ sodium pyruvate containing $10 \% \mathrm{FBS}$ in a humidified atmosphere containing $5 \% \mathrm{CO}_{2}$

To depolymerize MTs, interphase cells were treated with $10 \mu \mathrm{M}$ of nocodazole for $3 \mathrm{~h}$, washed with cold medium and incubated on ice for $1 \mathrm{~h}$. Mitotic cells were treated with $10 \mu \mathrm{M}$ of STLC for $6 \mathrm{~h}$, washed with cold medium and incubated on ice for $1 \mathrm{~h}$. Subsequently, both cells were incubated in medium containing $1 \%$ DMSO or $30 \mu \mathrm{M}$ of gatastatin for $10 \mathrm{~min}$ on ice. Cells were then put in warmed medium containing either $1 \%$ DMSO or $30 \mu \mathrm{M}$ of gatastatin and were incubated at $37^{\circ} \mathrm{C}$ (interphase cells) or $20^{\circ} \mathrm{C}$ (mitotic cells) for $1 \mathrm{~min}$. The cells were immediately fixed with cold $\mathrm{MeOH}\left(-20^{\circ} \mathrm{C}\right)$.

After blocking with PBS containing $0.5 \%$ bovine serum albumin, cells were incubated with anti-EB1 antibody (1:500 dilution, Abcam, Cat\# ab53358), anti- $\alpha$ tubulin antibody (1:500 dilution, Sigma, Cat\# T9026) and anti-pericentrin antibody (1:2,000 dilution, Abcam, Cat\# ab4448). After staining with Alexa ${ }^{555}$-conjugated anti-rat IgG (1:500 dilution, Molecular Probes), Alexa ${ }^{647}$-conjugated anti-mouse

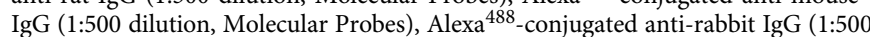
dilution, Molecular Probes) and $5 \mu \mathrm{g} \mathrm{ml}^{-1}$ Hoechst 33342, cells were washed four times with PBS and mounted with ProLong Gold Antifade Reagent (Life Technologies). MT nucleation was observed under a DeltaVision Olympus IX71 microscope (Applied Precision) equipped with CoolSNAP HQ camera (Photometrics)

EB3-EGFP signal tracking analysis. A HeLa 'Kyoto' cell line stably expressing EB3-EGFP (a kind gift from Dr J. Ellenberg) was maintained in DMEM + GlutaMAX (Gibco) supplemented with $10 \% \mathrm{FBS}, 2 \mathrm{mM} \mathrm{L-glutamine,} 100 \mathrm{U} \mathrm{ml}^{-1}$ penicillin, $100 \mu \mathrm{g} \mathrm{ml}^{-1}$ streptomycin, $1 \mathrm{mM}$ sodium pyruvate and $0.5 \mathrm{mg} \mathrm{ml}^{-1}$ G418. Cells were seeded into eight-well Lab-Tek chambers (Nunc, Rochester, NY) for 24-h prior imaging. For imaging, the medium was exchanged to Live Cell Imaging Solution (Molecular Probes Life Technologies) supplemented as described 
above and containing various concentrations of AG1 or gatastatin. Interphase cells were incubated with drugs for $15 \mathrm{~min}$ and mitotic cells were treated as described in Fig. 4c. Then, EB3 tracks were observed under a PerkinElmer UltraVIEW ERS Spinning Disk microscope (Software: UltraVIEW ERS Imaging Suite) equipped with a Plan-APOCHROMAT $\times 100 / 1.4$ Oil DIC objective, a Confocal Scanner Unit (Yokogawa CSU 22), a Hamamatsu EM CCD camera (C9100-50) and a 488$\mathrm{nm}$ Argon laser at $37^{\circ} \mathrm{C}$, and time-lapse sequences were performed for $60 \mathrm{~s}$ with a 400-ms interval. Automatic analysis of EB3-EGFP signal tracks was performed with ImageJ (http://imagej.nih.gov/ij/) and Matlab (Mathworks) as described ${ }^{16}$.

Analysis of interphase MT network and spindle structure. HeLa cells were cultured in DMEM containing 10\% FBS in a humidified atmosphere containing 5\% $\mathrm{CO}_{2}$. After treatment with each compound for $2.5 \mathrm{~h}$ (interphase MT network) or $5 \mathrm{~h}$ (mitotic spindle), the cells were immediately fixed with cold $\mathrm{MeOH}\left(-20^{\circ} \mathrm{C}\right)$. After blocking with PBS containing $0.5 \%$ bovine serum albumin, cells were incubated with anti- $\alpha$-tubulin antibodies (1:500 dilution, Santa Cruz, Cat\# sc-32293) to observe interphase cells, or with anti-BubR1 (1:250 dilution, BD Bioscience, Cat\# 612502) and anti- $\alpha$-tubulin (1:250 dilution, MBL, Cat\# PM054) antibodies to observe mitotic spindle. After staining with Alexa ${ }^{488}$-conjugated anti-mouse IgG (1:2,000 dilution, Invitrogen, Cat\#A11001) and Alexa568-conjugated anti-rabbit IgG (1:2000 dilution, Invitrogen, Cat\#A11011), cells were washed four times with PBS and mounted with PBS containing $0.1 \mu \mathrm{g} \mathrm{ml}^{-1}$ DAPI. MTs and BubR1 signals were observed under a Leica LAS AF 6000 fluorescence microscope (Leica Microsystems) or an LSM 700 laser-scanning confocal microscope (Zeiss).

\section{Measurement of spindle length of gatastatin-treated cells. Exponentially} growing HeLa cells were treated with $30 \mu \mathrm{M}$ of gatastatin for $9 \mathrm{~h}$. Cells were fixed with cold $\mathrm{MeOH}\left(-20^{\circ} \mathrm{C}\right)$. Immunostaining was performed as described above using anti- $\alpha$-tubulin (1:250 dilution, Santa Cruz, Cat\# sc-32293) and anti-pericentrin (1:250 dilution, Abcam, Cat\# ab4448) antibodies. After staining with Alexa ${ }^{488}$ conjugated anti-mouse IgG (1:2,000 dilution, Invitrogen, Cat\#A11001) and Alexa ${ }^{568}$-conjugated anti-rabbit IgG (1:2,000 dilution, Invitrogen, Cat\#A11011), cells were washed four times with PBS and mounted with PBS containing $0.1 \mu \mathrm{g} \mathrm{ml}^{-1}$ DAPI. Spindle structure was observed under a Leica LAS AF 6000 fluorescence microscope (Leica Microsystems). Images of 41 sections at $0.251-\mu \mathrm{m}$ intervals were collected. The position of the two pericentrin signals of mitotic cells was analysed using the ImageJ software, and then their distance was calculated.

\section{Analysis of the transition from $\mathbf{S}$ phase to mitotic entry. Cells expressing} EGFP- $\alpha$-tubulin and mCherry-H2B were prepared as described previously ${ }^{42}$. Cells were arrested at the $S$ phase with $2-\mathrm{mM}$ thymidine treatment for $15 \mathrm{~h}$. To determine the time required for mitotic entry from $\mathrm{S}$ phase release, thymidine was removed by washing cells with PBS three times. After treatment with $30 \mu \mathrm{M}$ gatastatin for $9 \mathrm{~h}$, time-lapse analysis was performed using DeltaVision Olympus IX71 microscope (Applied Precision) equipped with CoolSNAP HQ camera (Photometrics). Images were taken every $6 \mathrm{~min}$ with $12 \mathrm{z}$-stack ( $1 \mu \mathrm{m}$ per stack). During live cell imaging, cells were maintained at $37^{\circ} \mathrm{C}$ and were supplied with $5 \%$ $\mathrm{CO}_{2}$. The timing of the mitotic entry was defined by the chromosome condensation after nuclear envelope breakdown.

Bipolar spindle establishment and spindle length. To analyse bipolar spindle establishment from monopolar spindles, HeLa cells were arrested at prometaphase with $10 \mu \mathrm{M}$ of STLC for $15 \mathrm{~h}$. STLC was removed by washing cells with the medium three times. After treatment with $1 \%$ DMSO or $30 \mu \mathrm{M}$ of gatastatin for $2 \mathrm{~h}$, cells were immediately fixed with cold $\mathrm{MeOH}\left(-20^{\circ} \mathrm{C}\right)$.

For analysis of the length of the bipolar spindle in MG132-treated cells, HeLa cells were arrested at prometaphase with $10 \mu \mathrm{M}$ of STLC for $15 \mathrm{~h}$, followed by STLC removal by washing the cells with the medium three times to remove STLC. After treatment with $5 \mu \mathrm{M}$ of MG132 for $2 \mathrm{~h}, 1 \%$ DMSO or $30 \mu \mathrm{M}$ of gatastatin was added. Cells were incubated for $2 \mathrm{~h}$ (combined treatment with MG132 and gatastatin) and then immediately fixed with cold $\mathrm{MeOH}\left(-20^{\circ} \mathrm{C}\right)$.

Immunostaining was performed as described above using anti- $\alpha$-tubulin (1:250 dilution, Santa Cruz, Cat\# sc-32293) and anti-pericentrin (1:250 dilution, Abcam, Cat\# ab4448) antibodies. Spindle structure was observed under a Leica LAS AF 6000 fluorescence microscope (Leica Microsystems). The measurement of spindle length was performed as described above.

Analysis of gatastatin-treated spindle using 3D-SIM. To observe the effect of gatastatin on MG132-treated metaphase-like spindle using 3D-SIM (threedimensional structural illumination microscopy), HeLa cells were arrested at metaphase by sequential treatment with STLC and MG132. After treatment with $1 \% \mathrm{DMSO}$ or $30 \mu \mathrm{M}$ of gatastatin for $2 \mathrm{~h}$ (combination treatment with MG132 and gatastatin), cells were fixed with cold $\mathrm{MeOH}\left(-20^{\circ} \mathrm{C}\right)$. Cells were blocked with PBS containing $0.5 \%$ bovine serum albumin and then were incubated with anti- $\alpha$ tubulin (1:500 dilution, Sigma-Aldrich Cat\# T9026) and $\gamma$-tubulin (1:500 dilution, antibody against C-EYHAATRPDYISWGTQDK peptide of $\gamma$-tubulin ${ }^{43}$ ) antibodies. Secondary antibodies were Alexa ${ }^{488}$-conjugated anti-mouse IgG (1:500 dilution, Molecular Probes) and Alexa555-conjugated anti-rabbit IgG (1:500 dilution, Molecular Probes). DNA was stained with $0.5 \mu \mathrm{g} \mathrm{ml}{ }^{-1}$ Hoechst 33342 for 30 min. Finally, cells were washed four times with PBS and mounted in Prolong Gold Antifade (Molecular Probes, \#P36930). Spindle structure was observed under a 3D-SIM-Nikon Ti inverted microscope.

Analysis of the anaphase spindle elongation and cytokinesis. HeLa cells expressing mCherry-H2B and EGFP- $\alpha$-tubulin, HeLa 'Kyoto' cell line stably expressing CEP55-LAPtag (a kind gift from Dr A.A. Hyman) and HeLa cells expressing RFP-H2B and GFP-LifeAct (a kind gift from Dr J. Ellenberg) were cultured in DMEM + GlutaMAX (Gibco) supplemented with $10 \%$ FBS, $100 \mathrm{U} \mathrm{ml}^{-1}$ penicillin, $100 \mu \mathrm{g} \mathrm{ml}^{-1}$ streptomycin and $1 \mathrm{mM}$ sodium pyruvate in a humidified atmosphere containing $5 \% \mathrm{CO}_{2}$. To observe the transition from metaphase to anaphase, telophase and cytokinesis, cells were arrested at metaphase by sequential treatment of STLC and MG132. After MG132 removal by washing of cells with medium three times, the medium was changed to Live Cell Imaging Solution (Molecular Probes Life Technologies) supplemented as described above containing $1 \mu \mathrm{M}$ of MPS1 inhibitor reversine and either DMSO or $30 \mu \mathrm{M}$ of gatastatin. Time-lapse observation was performed at $37^{\circ} \mathrm{C}$ using the DeltaVision Olympus IX71 microscope (Applied Precision) equipped with CoolSNAP HQ camera (Photometrics). Images were taken every 3 min with 12 z-stacks $(1 \mu \mathrm{m}$ per stack) for $3 \mathrm{~h}$. The anaphase duration (between chromosome separation and start of midbody formation) was calculated.

\section{References}

1. Wiese, C. \& Zheng, Y. A new function for the $\gamma$-tubulin ring complex as a microtubule minus-end cap. Nat. Cell Biol. 2, 358-364 (2000).

2. Murphy, S. M. et al. GCP5 and GCP6: two new members of the human $\gamma$-tubulin complex. Mol. Biol. Cell 12, 3340-3352 (2001).

3. Kollman, J. M., Polka, J. K., Zelter, A., Davis, T. N. \& Agard, D. A. Microtubule nucleating $\gamma$-TuSC assembles structures with 13 -fold microtubule-like symmetry. Nature 466, 879-882 (2010).

4. Knop, M., Pereira, G., Geissler, S., Grein, K. \& Schiebel, E. The spindle pole body component Spc97p interacts with the $\gamma$-tubulin of Saccharomyces cerevisiae and functions in microtubule organization and spindle pole body duplication. EMBO J. 16, 1550-1564 (1997).

5. Geissler, S. et al. The spindle pole body component Spc98p interacts with the $\gamma$-tubulin-like Tub4p of Saccharomyces cerevisiae at the sites of microtubule attachment. ЕMBO J. 15, 3899-3911 (1996).

6. Kollman, J. M., Merdes, A., Mourey, L. \& Agard, D. A. Microtubule nucleation by $\gamma$-tubulin complexes. Nat. Rev. Mol. Cell Biol. 12, 709-721 (2011).

7. Yokosuka, A. et al. Glaziovianin A, a new isoflavone, from the leaves of Ateleia glazioviana and its cytotoxic activity against human cancer cells. Bioorg. Med. Chem. Lett. 17, 3091-3094 (2007).

8. Chinen, T. et al. Glaziovianin A prevents endosome maturation via inhibiting microtubule dynamics. ACS Chem. Biol. 8, 884-889 (2013).

9. Hayakawa, I., Ikedo, A., Chinen, T., Usui, T. \& Kigoshi, H. Design, synthesis, and biological evaluation of the analogues of glaziovianin A, a potent antitumor isoflavone. Bioorg. Med. Chem. 20, 5745-5756 (2012).

10. Yamazaki, Y. et al. Synthesis and structure-activity relationship study of antimicrotubule agents phenylahistin derivatives with a didehydropiperazine2,5-dione structure. J. Med. Chem. 55, 1056-1071 (2012).

11. Aldaz, H., Rice, L. M., Stearns, T. \& Agard, D. A. Insights into microtubule nucleation from the crystal structure of human $\gamma$-tubulin. Nature 435, 523-527 (2005).

12. Guillet, V. et al. Crystal structure of $\gamma$-tubulin complex protein GCP4 provides insight into microtubule nucleation. Nat. Struct. Mol. Biol. 18, 915-919 (2011).

13. Sardar, P. S., Maity, S. S., Das, L. \& Ghosh, S. Luminescence studies of perturbation of tryptophan residues of tubulin in the complexes of tubulin with colchicine and colchicine analogues. Biochemistry 46, 14544-14556 (2007).

14. Gombos, L. et al. GTP regulates the microtubule nucleation activity of $\gamma$-tubulin. Nat. Cell Biol. 15, 1317-1327 (2013).

15. Luders, J., Patel, U. K. \& Stearns, T. GCP-WD is a $\gamma$-tubulin targeting factor required for centrosomal and chromatin-mediated microtubule nucleation. Nat. Cell Biol. 8, 137-147 (2006).

16. Sironi, L. et al. Automatic quantification of microtubule dynamics enables RNAi-screening of new mitotic spindle regulators. Cytoskeleton (Hoboken) $\mathbf{6 8}$, 266-278 (2011)

17. Paluh, J. L. et al. A mutation in $\gamma$-tubulin alters microtubule dynamics and organization and is synthetically lethal with the kinesin-like protein pkllp. Mol. Biol. Cell 11, 1225-1239 (2000).

18. Jung, M. K., Prigozhina, N., Oakley, C. E., Nogales, E. \& Oakley, B. R. Alanine-scanning mutagenesis of Aspergillus $\gamma$-tubulin yields diverse and novel phenotypes. Mol. Biol. Cell 12, 2119-2136 (2001).

19. Hughes, S. E. et al. $\gamma$-Tubulin is required for bipolar spindle assembly and for proper kinetochore microtubule attachments during prometaphase I in Drosophila oocytes. PLoS Genet. 7, e1002209 (2011). 
20. Bouissou, A. et al. $\gamma$-Tubulin ring complexes regulate microtubule plus end dynamics. J. Cell Biol. 187, 327-334 (2009).

21. Khodjakov, A. \& Rieder, C. L. The sudden recruitment of $\gamma$-tubulin to the centrosome at the onset of mitosis and its dynamic exchange throughout the cell cycle, do not require microtubules. J. Cell Biol. 146, 585-596 (1999).

22. Hewitt, L. et al. Sustained Mps1 activity is required in mitosis to recruit O-Mad2 to the Mad1-C-Mad2 core complex. J. Cell Biol. 190, 25-34 (2010).

23. Santaguida, S., Tighe, A., D’Alise, A. M., Taylor, S. S. \& Musacchio, A. Dissecting the role of MPS1 in chromosome biorientation and the spindle checkpoint through the small molecule inhibitor reversine. J. Cell Biol. 190, 73-87 (2010).

24. Zhao, W. M., Seki, A. \& Fang, G. Cep55, a microtubule-bundling protein, associates with centralspindlin to control the midbody integrity and cell abscission during cytokinesis. Mol. Biol. Cell 17, 3881-3896 (2006).

25. Vardy, L. \& Toda, T. The fission yeast $\gamma$-tubulin complex is required in G1 phase and is a component of the spindle assembly checkpoint. EMBO J. 19, 6098-6111 (2000)

26. Hutchins, J. R. et al. Systematic analysis of human protein complexes identifies chromosome segregation proteins. Science 328, 593-599 (2010).

27. Lecland, N. \& Luders, J. The dynamics of microtubule minus ends in the human mitotic spindle. Nat. Cell Biol. 16, 770-778 (2014).

28. Julian, M. et al. gamma-Tubulin participates in the formation of the midbody during cytokinesis in mammalian cells. J. Cell Sci. 105, 145-156 (1993).

29. Katsetos, C. D. et al. Class III $\beta$-tubulin and $\gamma$-tubulin are co-expressed and form complexes in human glioblastoma cells. Neurochem. Res. 32, 1387-1398 (2007).

30. Godinho, S. A. et al. Oncogene-like induction of cellular invasion from centrosome amplification. Nature 510, 167-171 (2014).

31. Lin, T. C. et al. Cell-cycle dependent phosphorylation of yeast pericentrin regulates $\gamma$-TuSC-mediated microtubule nucleation. eLife 3, e02208 (2014)

32. Castoldi, M. \& Popov, A. V. Purification of brain tubulin through two cycles of polymerization-depolymerization in a high-molarity buffer. Protein Expr. Purif. 32, 83-88 (2003).

33. Goedert, M. \& Jakes, R. Expression of separate isoforms of human tau protein: correlation with the tau pattern in brain and effects on tubulin polymerization. EMBO J. 9, 4225-4230 (1990).

34. Desai, A. \& Mitchison, T. J. Preparation and characterization of caged fluorescein tubulin. Methods Enzymol. 298, 125-132 (1998).

35. Hyman, A. A., Salser, S., Drechsel, D. N., Unwin, N. \& Mitchison, T. J. Role of GTP hydrolysis in microtubule dynamics: information from a slowly hydrolyzable analogue, GMPCPP. Mol. Biol. Cell 3, 1155-1167 (1992).

36. Yokota, H. et al. Single-molecule visualization of binding modes of helicase to DNA on PEGylated surfaces. Chem. Lett. 38, 308-309 (2009).

37. Schindelin, J. et al. Fiji: an open-source platform for biological-image analysis. Nat. Methods 9, 676-682 (2012).

38. Hannak, E. \& Heald, R. Investigating mitotic spindle assembly and function in vitro using Xenopus laevis egg extracts. Nat. Protoc. 1, 2305-2314 (2006).

39. Wittmann, T., Wilm, M., Karsenti, E. \& Vernos, I. TPX2, a novel Xenopus MAP involved in spindle pole organization. J. Cell Biol. 149, 1405-1418 (2000).

40. Barenz, F. et al. The centriolar satellite protein SSX2IP promotes centrosome maturation. J. Cell Biol. 202, 81-95 (2013).

41. Yokoyama, H. et al. Cdk11 is a RanGTP-dependent microtubule stabilization factor that regulates spindle assembly rate. J. Cell Biol. 180, 867-875 (2008).

42. Neumann, B. et al. Phenotypic profiling of the human genome by time-lapse microscopy reveals cell division genes. Nature 464, 721-727 (2010).

43. Zheng, Y., Wong, M. L., Alberts, B. \& Mitchison, T. Nucleation of microtubule assembly by a $\gamma$-tubulin-containing ring complex. Nature $\mathbf{3 7 8 , 5 7 8 - 5 8 3}$ (1995).

\section{Acknowledgements}

We thank U. Jäkle for protein purification, the University of Colorado Boulder, protein expression facility, for the gift of human $\gamma$-tubulin-expressing virus, A. Merdes (Centre de Recherche en Pharmacologie-Santé) for the gift of GCP4 expressing plasmid,

J. Ellenberg, L. Sironi (EMBL Heidelberg) and members of the ZMBH imaging facility for helpful suggestions for the analysis of EB3-EGFP-expressing HeLa cells. We thank S. Enya and R. Niwa for the help with the confocal microscopy analysis. For Xenopus experiments, we thank Y. Hao (ZMBH Heidelberg) for support with the egg extract preparations, and H. Yokoyama (Friedrich Miescher Laboratory Tübingen) for help with the quantification. We thank Heidelberg University-Nikon Imaging Center for the SIM analysis. We are grateful to A.A. Hyman and J. Ellenberg for HeLa cell lines. S. Hata and F.G. Agircan are acknowledged for helpful suggestions. We are also thankful to I. Hagan (Cancer Research UK Manchester Institute) for comments on the manuscript. This work was supported by a Grant-in-Aid for Scientific Research on the Innovative Area 'Chemical Biology of Natural Products' and 'Spying Minority in Biological Phenomena' from The Ministry of Education, Culture, Sports, Science and Technology, Japan, by Japan Society for the Promotion of Science (JSPS), KAKENHI including a Grant-in-Aid for Scientific Research 23390029, 24659092, 25113723, 25293046 and Platform for Drug Discovery, by a Grant-in-Aid for JSPS Fellows, and by the strategic programmes for R\&D (President's discretionary fund) of RIKEN. The work of E.S. was supported by a grant from the Deutsche Forschungsgemeinschaft Schi295/4-2. T.C. was supported by the Uehara memorial foundation and JSPS Postdoctoral Fellowships for Research Abroad. T.S. was supported by the Special Postdoctoral Researcher (SPDR) programme in RIKEN. J.P., T.-c.L., P.L. and B.C. are members of the International Graduate School HBIGS.

\section{Author contributions}

T.C. designed and performed experiments in Figs $1 \mathrm{~b}-\mathrm{d}, \mathrm{f}, 2,3 \mathrm{a}, \mathrm{g}, \mathrm{h}, 4 \mathrm{a}-\mathrm{d}$ and 5 and Tables 1 and 2, analysed in Fig. 3c-f and prepared the manuscript and all figures. P.L. and O.G. performed experiments in Fig. 1e,f. S.S. synthesized AG1 and gatastatin. J.P. performed the analysis in Figs $3 \mathrm{~b}$ and $4 \mathrm{e}$ and Tables 3 and 4. B.C. performed experiments in Fig. 3c-f. T.-c.L. performed experiments in Tables 1. Y.H. and H.T. synthesized plinabulin and KPU-406. T.S. and Y.O. performed experiments in Figs 1b,c. I.H. and H.K. designed the schemes to synthesize AG1 and gatastatin. Y.H. designed the schemes to synthesize plinabulin and KPU-406. T.U. and E.S. directed the project and designed experiments and prepared the manuscript. All authors helped in writing the manuscript.

\section{Additional information}

Supplementary Information accompanies this paper at http://www.nature.com/ naturecommunications

Competing financial interests: The authors declare no competing financial interests.

Reprints and permission information is available online at http://npg.nature.com/ reprintsandpermissions/

How to cite this article: Chinen, T. et al. The $\gamma$-tubulin-specific inhibitor gatastatin reveals temporal requirements of microtubule nucleation during the cell cycle. Nat. Commun. 6:8722 doi: 10.1038/ncomms9722 (2015).

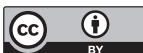

This work is licensed under a Creative Commons Attribution 4.0 International License. The images or other third party material in this article are included in the article's Creative Commons license, unless indicated otherwise in the credit line; if the material is not included under the Creative Commons license, users will need to obtain permission from the license holder to reproduce the material. To view a copy of this license, visit http://creativecommons.org/licenses/by/4.0/ 